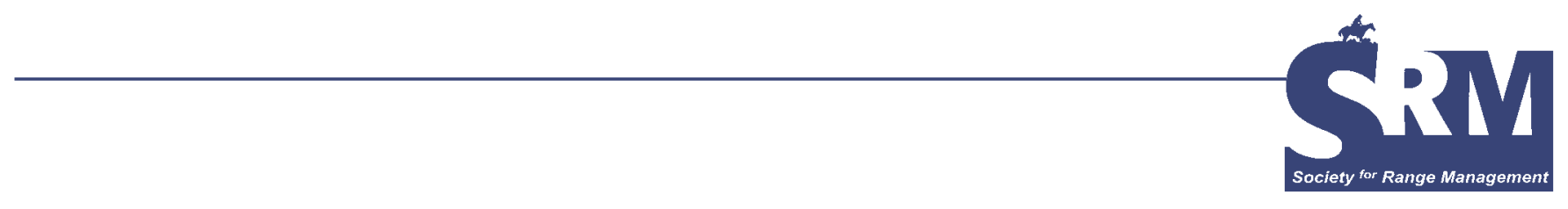

\title{
The Colorado Section Youth Program
}

\section{By Ben Berlinger}

"Perhaps the most serious obstacle impeding the evolution of a land ethic is the fact that our educational and economic system is headed away from, rather than toward, an intense consciousness of the land.

"The problem, then, is how to bring about a striving for harmony with land among a people many of whom have forgotten that there is any such thing as land, among whom education and culture have become almost synonymous with landlessness."

-Aldo Leopold, from "A Sand County Almanac, and Sketches Here and There" (New York, NY: Oxford University Press; 1948)

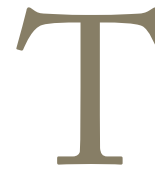

hese quotes from Aldo Leopold are at the heart of the youth program of the SRM's Colorado Section. The Section has had a long-running history of strong support for youth education and awareness of our rangeland resources. The program is guided by the Youth Affairs Committee, a standing committee within the structure of the Section.

\section{Camp Rocky}

History

Colorado's premier outdoor environmental education program for high school youth has long been Camp Rocky. The Camp had its beginnings in the mid-1950s! In its earlier years this program was known as Colorado's Youth Conservation Workshop. It was then directed by the Colorado State University (CSU) Cooperative Extension. Camp Rocky was born when CSU restructured and dropped the program about
9 years ago. The Colorado Association of Conservation Districts stepped up to the plate and assumed the administration of the program. The Camp is codirected by the Colorado State Forest Service with many program partners, including the Colorado Section SRM and the Colorado Chapter of the Soil and Water Conservation Society.

\section{The Program}

Camp Rocky is a weeklong residential camp for 14- through 19-year-olds who enjoy the out-of-doors and are interested in natural resources. Camp Rocky staff, made up of resource

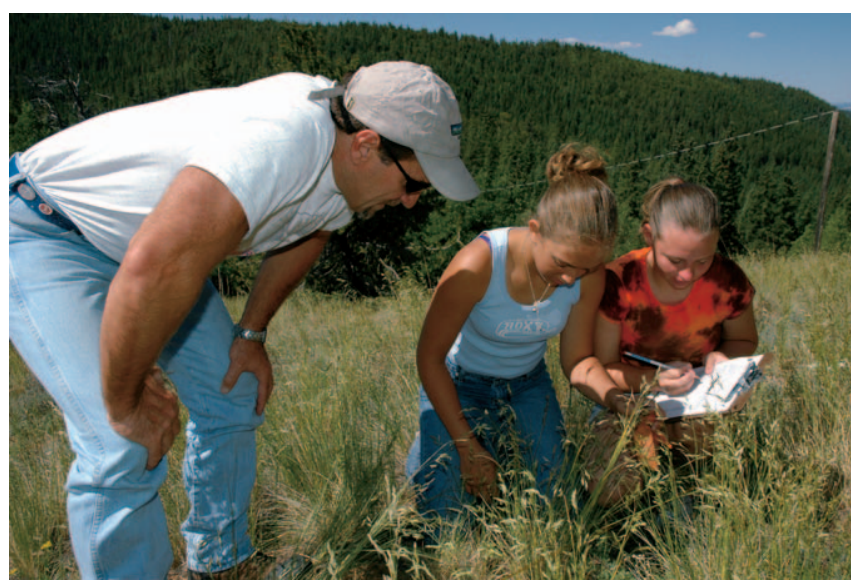

Colorado Section member Dan Nosal assists Camp Rocky rangeland science students as they complete their field inventories. Photo courtesy of US Department of Agriculture-National Resource Conservation Service (USDA-NRCS). 
professionals from around the state, help participants learn about our environment while working in teams and meeting other students from across Colorado.

Students choose from one of the following resource fields for their area of focus: rangeland science, soil and water conservation, forest management, and wildlife management. During the second half of the week, students from the 4 different resource teams work in new, integrated management teams to develop and present natural resource management plans. Participants also explore, discuss, and use critical thinking and problem-solving techniques to find solutions for various controversial environmental issues. For the rangeland science team members, past issues have been prairie dog management, public land grazing, feral horses and burros, and the Endangered Species Act. There is still plenty of time for fun, though, with group learning exercises such as setting up a llama short-duration grazing demonstration, rangeland Jeopardy, Colorado rangeland types, and nature trail hikes!

Each year the Colorado Section recognizes 2 of the outstanding students in the rangeland science group. SRM belt buckles are awarded to those students who, during the week, have shown the most interest and have come the furthest toward enhancing their knowledge and understanding of rangelands.

\section{Black Mesa Ecological Academy Multi-SRM Section Involvement}

The rangeland camp for high school students at Black Mesa is an SRM-sponsored function involving 5 Sections: Colorado, Oklahoma, New Mexico, Texas, and Kansas. It was started in 2002 when the Oklahoma Section decided to move its range camp to the panhandle and invited the surrounding states to participate. The Cimarron County Conservation District stepped up to the plate and agreed to host the event just outside of Kenton, Oklahoma.

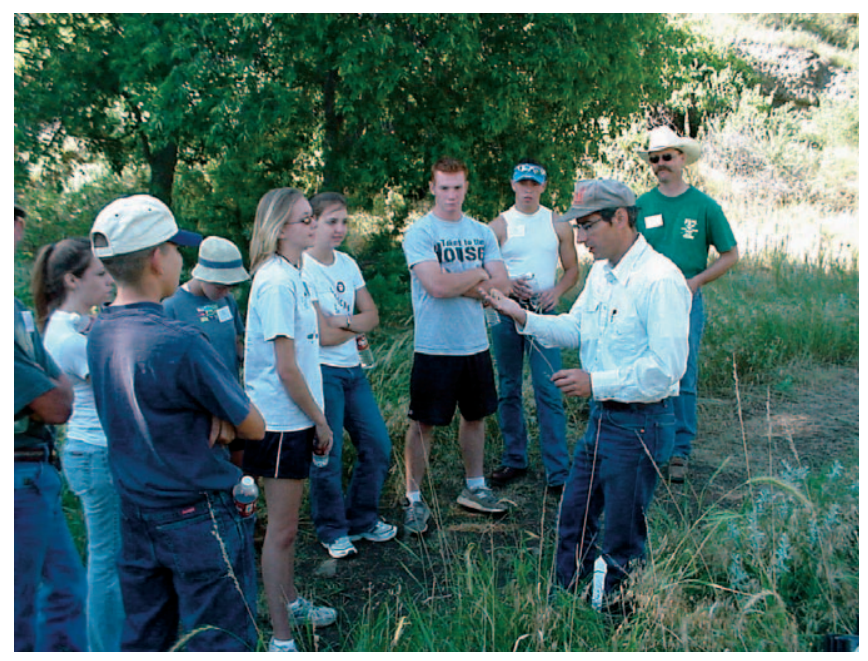

Range plant identification exercise at the Black Mesa Ecological Academy. Ben Berlinger (foreground, holding plant) and Dwayne Rice, Kansas Section (background), lead the demonstration. Photo courtesy of USDA-NRCS.
"All of us are smarter than one of us" could be the theme of the Academy. The weeklong program at the Academy begins with a challenge course, a tool used to build teamwork, teach problem solving, and cultivate self-confidence. The topics included in the curriculum include basic ecological principles, a plant identification and collection competition, leadership and speaking skills, and resource planning integrating the use of Global Positioning System satellite and Geographic Information System technologies.

During the latter half of the week the students participate in the identification of natural resource concerns and the development of a land management plan. This information forms the basis for working in teams to prepare a rangeland management plan based on objectives. This exercise brings together the skills in problem solving and teamwork.

A unique aspect of the Academy is the involvement of the students in activities that include a "tour" through the history of the southern Great Plains region, starting with the early Native American culture and ending with the present-day inhabitants. The foods as well as other aspects of the culture and historical living skills are featured during the entire week.

Section presidents and parents are invited to attend the awards luncheon on the last day of the Academy. Each Section recognizes its top camper, and the Academy staff award the "Trail Boss" to recognize the highest overall achiever at the Academy. Finally, the students vote on and recognize one of their own with a "Top-Hand" award.

\section{FFA Rangeland Judging}

The Colorado Section involves many members located throughout the state in numerous high school FFA Voc/ $\mathrm{Ag}$ rangeland judging activities. These are mostly the district contests held in the fall near the start of the school year. Members also help with the instruction and field practice events as students prepare for the contests.

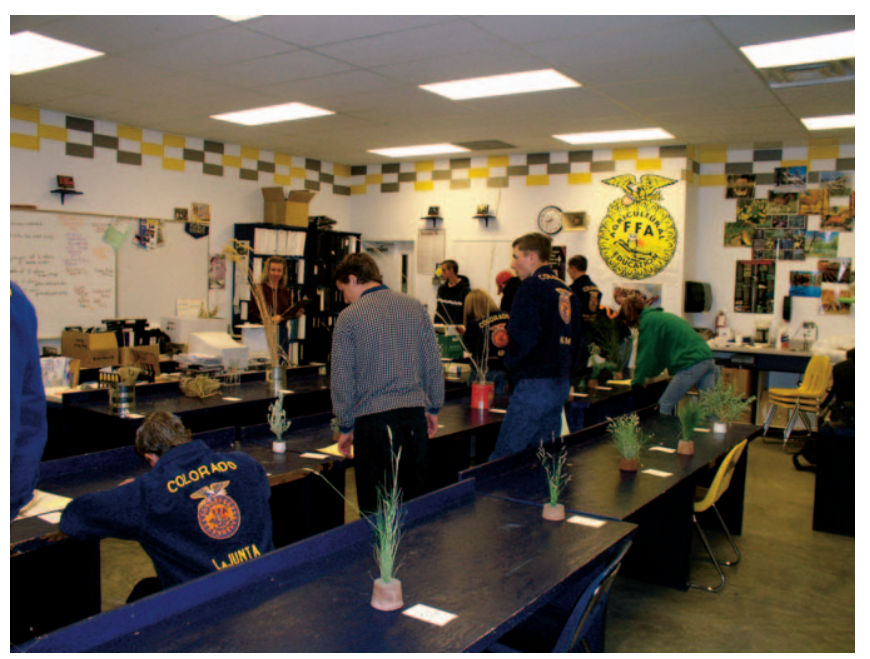

Colorado Section member Kimberly Diller (background, in brown shirt) supervises the plant identification part of the FFA rangeland judging contest at the San Isabel District. This part of the contest is usually held indoors using preserved or mounted specimens. Photo courtesy of USDA-NRCS. 
The contest in Colorado involves 2 parts: the identification and characterization of 50 rangeland plants and the identification of 2 ecological sites together with determining rangeland similarity index, plant basal cover, proper stocking rates, apparent rangeland trend, and recommended management practices based on stated goals and objectives.

The highlight of the FFA rangeland judging program is the state contest. The location is rotated each year among 3 sites in eastern Colorado. Upwards of 120 students participate and "dot" the eastern Colorado plains with their blue FFA coats during the contest!

\section{High School Youth Forum}

The Colorado Section strongly supports the SRM High School Youth Forum as one of the foremost opportunities to learn about rangelands. The Section sponsors 1 to 3 high

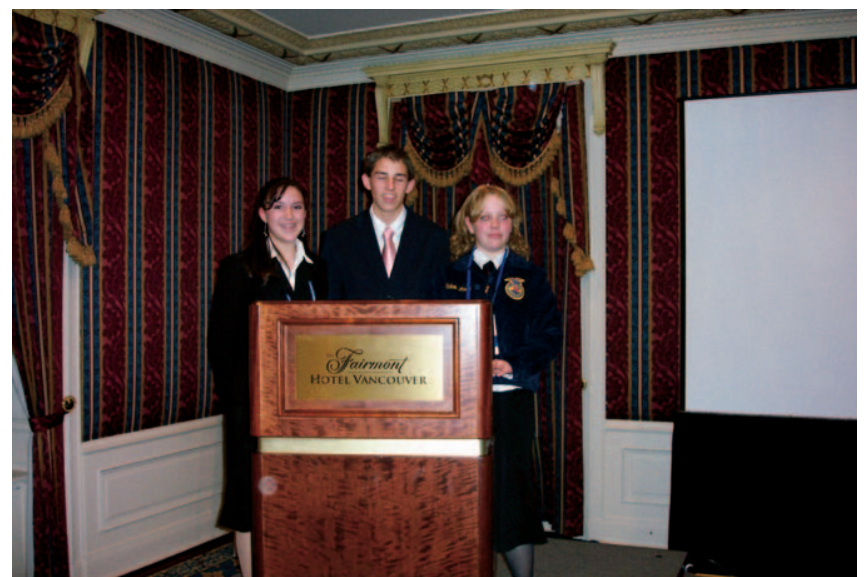

Colorado Section delegates to the 2006 High School Youth Forum held in Vancouver, British Columbia, were (left to right) Kaitlyn Lingus, Branson, Colorado; Jake Meinzer, Yoder, Colorado; and Nikki Jorbin, Agate, Colorado. Kaitlyn was recognized with third place honors for her illustrated talk during the paper presentation contest. Photo courtesy of John Mitchell, US Forest Service, Fort Collins, Colorado. school youth to participate at each Forum. Section members from all over the state, from Fort Collins to Trinidad, help prepare these students for the daunting task of writing and presenting their papers for the illustrated talk competition! The top performers from Camp Rocky and the Black Mesa Ecological Academy, as well as the high achiever in the Agate High School's rangeland management curriculum, are chosen as potential delegates to the Forum.

As with the other SRM Sections, our Forum delegates are quick to understand the awesome responsibility they have been given. Likewise, as with other Sections, our membership will attest that much work is required on our parts. However, the reward is, without saying, great, as we proudly watch, with much anticipation, their presentations and a job well done!

\section{The Benefits}

Through both austere and good budget years, the Colorado Section Board of Directors has shown strong support for the youth of Colorado. Many positive outcomes have resulted from the SRM youth program in Colorado. As with all education programs, some of the benefits are measurable but most are not. Some of our youth continue in the field of rangeland science and move on to the university level, leading to a professional degree. Obviously, the most rewarding outcome is to see these youth employed in a rangeland management career, be that with a government agency, extension service, university, or private business! All indications are that this support will continue for the benefit of future generations of Colorado youth!

Author is the current chairperson of the Colorado Section Youth Affairs Committee. He is employed as a Rangeland Management Specialist, Natural Resources Conservation Service, La Junta, CO 81050,ben.berlinger@co.usda.gov. 